\title{
港湾・空港工事におけるグリーン調達品目の 適用に関する考察
}

\section{STUDY ON GREEN PURCHASING FOR PORT AND AIRPORT CONSTRUCTION}

\author{
内藤 了 $^{1} \cdot$ 東海林 $^{\text {恭一 }}{ }^{2} \cdot$ 畑田 武見 $^{3}$ \\ Ryo-ji NAITO, Kyouichi SHOUJI and Takemi HATAKEDA \\ ${ }^{1}$ 正会員 (独)港湾空港技術研究所 海洋・水工部 沿岸環境領域 \\ (元：国土交通省国土技術政策総合研究所 港湾研究部 港湾施工システム課) \\ （广239-0826神奈川県横須賀市長澒 3-1-1） \\ 2 国十交通省 国土技術政策総合研究所 港湾研究部 港湾施丁システム課 \\ （广239-0826 神奈川県横須賀市長瀬 3-1-1） \\ ${ }^{3}$ 国土交通省 東北地方整備局 港湾空港部 港湾事業課 \\ (元：国土交通省国土技術政策総合研究所 港湾研究部 港湾施工システム課) \\ （干980-0013 宮城県仙台市青葉区花京院 1-1-20）
}

\begin{abstract}
Law on Promoting Green Purchasing was enforced on 2001. This paper studied the existing state of the Green Purchasing associated with the Law, for public works of port and airport construction. Then the key point of the promotion of procurement of eco-friendly goods and materials by the State and other is considered. This paper presents, as a supporting tool for promotion of Green Purchasing, guidebook of eco-friendly goods and materials for port and airport construction use and reported cases of Green Purchasing of eco-friendly goods and materials.
\end{abstract}

Key Words: eco-friendly goods, green purchasing

\section{1. はじめに}

主要な資源の大部分を輸入に依存している我が国にお いては，大量生産・大量消費・大量廃棄社会から循環型 社会へと社会経済構造を抜本的に変革することが重要な 政策課題となっている. ${ }^{1)}$

地球温暖化問題や廃棄物問題をはじめ, 今日の我が国 が抱える環境問題は，その原因となる大量生産・大量廃 棄の社会構造に根ざしており, その解決には, 環境負荷 の少ない持続的発展が可能な社会に変革していくことが 重要となっている.

循環型社会経済システムを構築するに当たっては, 公 共事業の責務も非常に重要であるため, 公共事業におい て先導的にリサイクルの推進に取り組む仕組みを構築す ることが不可欠である.

これまで, 港湾・空港工事においても, 浚渫土砂の有 効利用, 舖装撤去材等の再生利用, スラグ材の受け入れ を行い，それに必要な技術開発を国土交通省港湾局では 行ってきたが，今後もリサイクルが円滑に進むことが期 待されている.
平成 12 年には，「循環型社会形成推進基本法」の制定 とあわせて,「建設工事にかかる資材の再資源化等に関す る法律」の制定，「再生資源の利用の促進に関する法律」 の改正が行われるなど制度的な枠組みが強化された。 ま た，国土交通省港湾局においては港湾・空港工事におけ るリサイクルの推進方策として,「港湾・空港等整備にお けるリサイクルガイドライン」を策定している. ${ }^{2)}$

その後, リサイクルをより一層推進することを誘導す るため, 国等の公的機関が自ら率先して環境物品等の調 達を推進し, 我が国全体の環境物品等への需要の転換を 図ることが重要となり，こうした背景のもと環境負荷の 少ない持続可能な循環型社会の構築に向け「国等による 環境物品等の調達の推進等に関する法律」（以下「グリー ン購入法」という）が平成 13 年 4 月に施行された.

このような背景をうけ, 公共工事については, 国土交 通省を中心として順次特定調達品目の選定, 調達を実施 してきた. 本研究では, 港湾・空港工事においてグリー ン調達の普及推進を図ることを目的とし, 特定調達品目 および特定調達品目候補群（以下，ロングリスト品目） 
表-1 解説資料に記載した環境物品と用途

\begin{tabular}{|c|c|c|c|}
\hline & 環境物品名称 & 指定の種類 & 港湾·空港工事での用途 \\
\hline \multirow[t]{2}{*}{ 建設副産物 } & 再生骨材等（コンクリート塊） & 特定調達品目 & 路盤工 \\
\hline & 建設污泥から再生した処理土 & 特定調達品目 & 路盤工 \\
\hline \multirow[t]{5}{*}{ 製鉄副産物 } & 高炬セメント & 特定調達品目 & コンクリートエ・地盤改良エ \\
\hline & 高炉スラグ骨材 & 特定調達品目 & コンクリートエ \\
\hline & 土工用水碚スラグ & 特定調達品目 & 裏込め·盛土・覆土・裏埋工 \\
\hline & 地盤改良用製鋼スラグ & 特定調達品目 & サンドコンパクションパイルエ \\
\hline & 鉄鋼スラグ水和固化体 & ロングリスト品目 & 消波ブロック・根固め・被覆ブロックエ \\
\hline \multirow{2}{*}{$\begin{array}{l}\text { フェロニッケルス } \\
\text { ラグ製造副産物 }\end{array}$} & フェロニッケルスラグ骨材 & 特定調達品目 & コンクリートエ \\
\hline & フェロニッケルスラグを用いたケーソン中詰め材 & 特定調達品目 & 中詰工 \\
\hline \multirow[t]{2}{*}{ 製銅副産物 } & 銅スラグ骨材 & 特定調達品目 & コンクリートエ \\
\hline & 銅スラグを用いたケーソン中詰め材 & 特定調達品目 & 中詰工 \\
\hline 再生プラスチック & 再生 PET 樹脂を用いた防砂シート (吸出し防止材) & 特定調達品目 & 吸出し防止工 \\
\hline 再生コンクリート & コンクリート煷を用いたコンクリート & ロングリスト品目 & コンクリートエ \\
\hline \multirow[t]{2}{*}{ その他 } & 天然繊維を用いたドレーン材 & ロングリスト品目 & パーチカルドレーンエ \\
\hline & 生分解性プラスチックを用いたドレーン材 & ロングリスト品目 & パーチカルドレーンエ \\
\hline
\end{tabular}

のうち, 港湾・空港工事において主要資材となる物品 (表 -1）について, 品質・性能等及び設計・施工上の留意事 項をまとめたグリーン調達品目の解説資料を作成した. また，それらの環境物品の適用実態調査を実施し事例集 としてまとめた.

港湾・空港工事に適用できる環境物品等の種類は多岐 にわたる。

その適用にあたり資材の用途別に設計・施工上の留意 事項や全国規模の調達実績を整理した研究はみあたらな い.

これらの整理をふまえて, 本研究ではグリーン調達普 及推進の方策を提案し，今後の技術課題について考察を 行った.

\section{2. グリーン調達の状況}

\section{(1) 調達実績}

港湾・空港工事におけるグリーン調澾品目（以下、環 境物品という）の調達状況及び普及実態の調査を実施し た. 表-1に示す特定調達品目について適用率の違いを調 べた.
なお，“適用率”とは港湾・空港工事（直轄）全体の使 用量に対する環境物品の使用量の割合である. 適用率の 経年変化を図-1 に示寸. その結果, 建設污泥から再生し た処理土およびコンクリート用スラグ骨材（高炉スラグ 骨材，フェロニッケルスラグ骨材，銅スラグ骨材）は適 用率が小さいこと, 再生骨材等, 高炉セメント, 再生材 料を用いた防砂シートは適用率が高いことがわかる．統 計期間が短いため明確なトレンドがある材料ばかりでは ないが, 図-1より, 環境物品の適用率が年々増加傾向に あることが判明した。

港湾・空港工事における環境物品の中で特に種類が多 いスラグ系材料について以下に詳述する.

コンクリート用骨材としての利用は，比重が大きいと いう性質を生かして消波ブロック等の重量コンクリート に使用されている。

土工用，地盤改良用および中詰材料としての利用は， 砂の代替材料としてよく使用されている.

特に, 水砕スラグは軽量埋立材, 製鋼スラグはサンド コンパクションパイル材, フェロニッケルスラグおよび 銅スラグはケーソン中詰材への適用事例が多い.

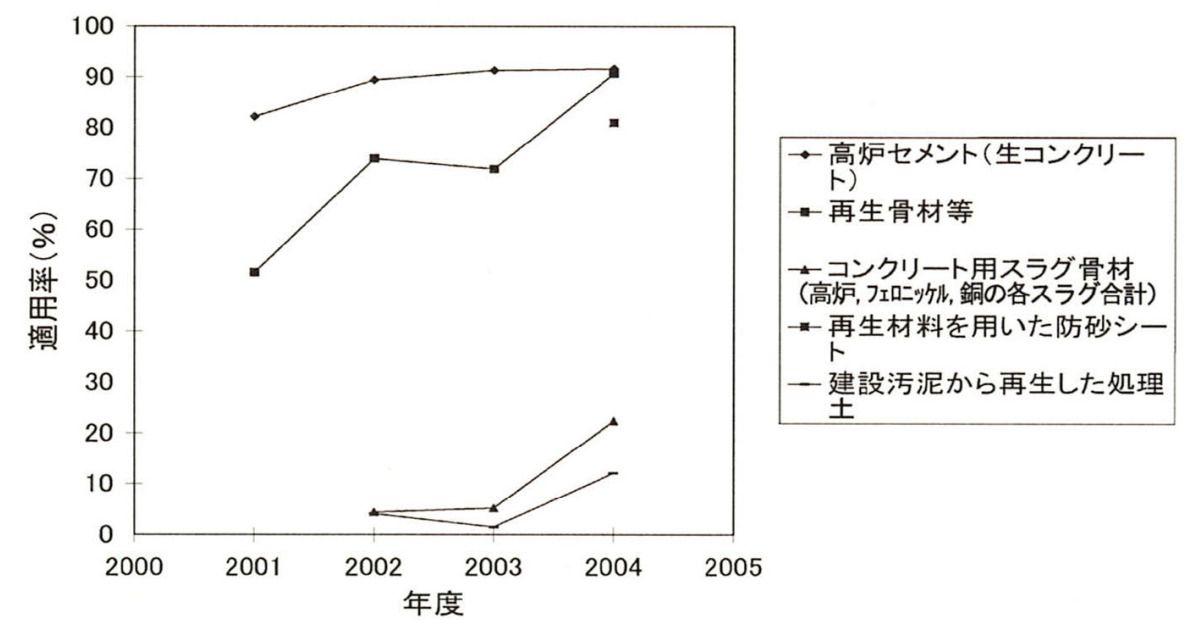

図-1＼cjkstart環境物品の普及実態 


\section{(2)調達できなかった主な理由}

調達が少ない原因を調べてみると，(1)供給上の問題と (2)材料の特性（品質）上の問題がある。前者は供給側と 調達側の相互理解の不足によるものであり，後者は設計 条件や施工条件およびその材料固有の特性によるもので あると考えられる。

\section{3. グリーン調達の推進策}

\section{(1) グリーン調達推進のポイント}

調達実績の調査より，グリーン調達の阻害要因として は，供給側の問題と調達側の問題の両方があり，これら を解決することがグリーン調達推進のために重要である と考えられる.ここでは, 調達側と供給側の両方の観点 から抽出した問題と解決策について整理した.

まず，調垟側の問題解決策としては，以下のことが考 えられる。

(1)環境物品の本質（物理・化学的性質, 而久久性, 環境 への長期的な影響の有無，適用分野，通常使用されて いる物品と比較した場合の安定性・供給性・コス卜等) を理解して適材適所に使用すること。

(2)グリーン調達の普及を支援するためのツールを整備 すること，すなわち，調達担当者が環境物品の特性を 把握し，港湾・空港工事において，どの施設のどの部 位にその環境物品を使うとよいかを分かりやすく説明 した資料が必要であると考えられる。

(3)材料の特性を有効に活用するには, 設計段階から環 境物品のもつ利点を活用した適用を検討すること.

(4)調達体制の簡素化・明確化を行ってグリーン調達が し易い環境を整備すること，例えば，前例がなくても 積極的に調垟できるような枠組みをつくること．

(5)現場の地域特性を考慮した調達を行うこと.

(6)一件の工事において複数の工種に環境物品が調達で きる場合は, 可能な限り調達品目を増や寸こと.

(7)通常使用されている物品が，自然環境の悪化に大き な影響を及ぼしている場合は，その物品の調達を法令 等で禁止すること．例えば，瀬戸内海における海砂の 採取禁止など ${ }^{3)}$ の事例がある.
一方，供給側の問題解決策としては，以下のことが考 えられる.

(1)グリーン購入法の主旨に適合した環境物品の分かり やすい説明資料を提供すること．すなわち，環境面の メリットおよびその物品の供用性が確認できる内容の 資料

(2)調達担当者は，環境物品の性能を保証する手がかり を求めているため，第三者機関による民間技術の評価 制度や新技術情報提供システム(NETIS)等を活用し客 観的な評価を受けること.

(3)調達担当者は, グリーン調達の推進だけでなく, 事 業のコスト縮减にも取り組んでいるため，環境物品の 価格は，通常使用されている物品と同程度かそれ以下 であること。

(4)環境物品の流通システムの整備等を行って，供給上 の問題が発生しないようにすること.

\section{（2）グリーン調達品目の解説資料}

港湾·空港工事において主に適用している環境物品(表 -1）について，既往の文献による調査及びヒアリング調 查等を行い，物理化学的特性，建設資材としてのメリッ ト，調達のし易さ，使用実績，適用に当たっての留意事 項等を調べるとともに，港湾・空港工事への適用性が高 いと考えられる品目について，設計及び施工管理のため の技術上の基本的事項，特に材料の特徴，施工方法等を 中心に整理し，グリーン調達推進のためのツールとする ために解説資料としてまとめた.

(1)ケーソン中詰材用スラグ

図-2 は，フェロニッケルスラグをケーソン中詰材と して用いた例である．施工場所がフェロニッケル精鍊 所に近く調達コストが砂と同程度であること, 及び基 礎地盤が良好なため, 砂より単位体積重量の大きい八 エロニッケルスラグを採用することによってケーソン の幅を縮小することができることも適用の大きな理由 になっている．同様の理由で銅スラグについてもケー ソン中詰材用として用いられている.

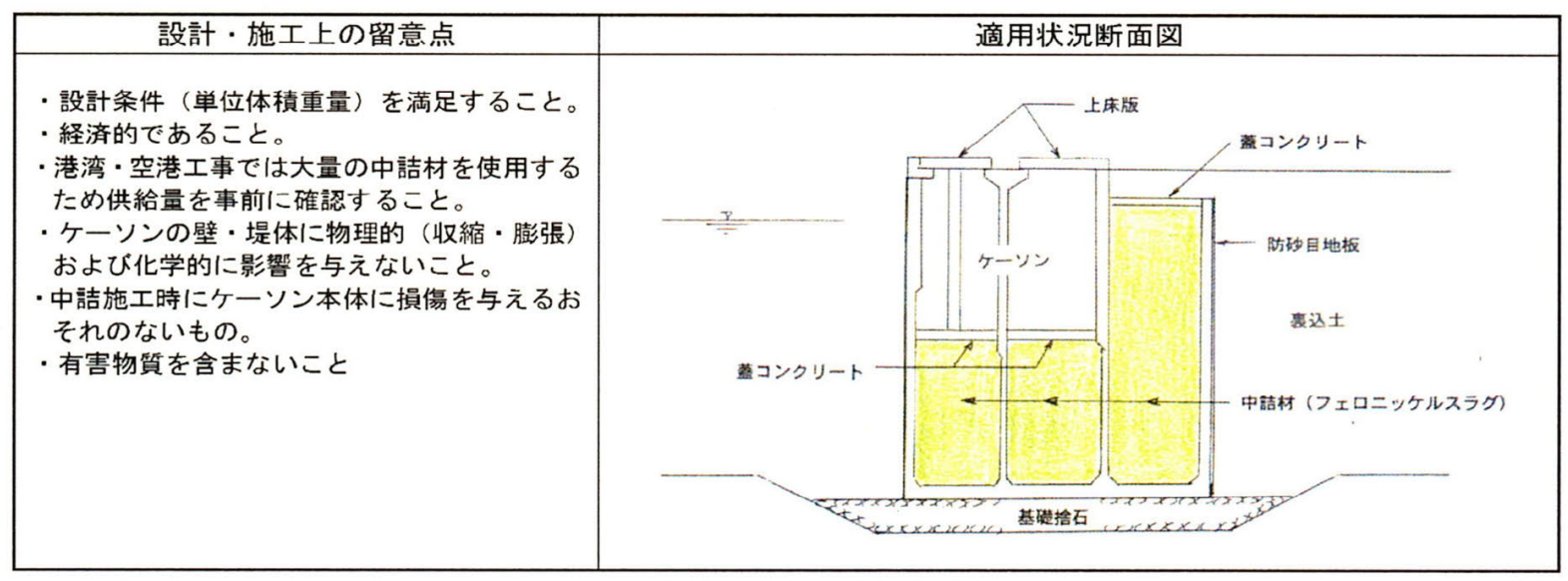

図-2ケーソン中詰工へのフェロニッケルスラグの適用例 


\section{(2)高炉水砕スラグ}

図-3に示す高炉水砕スラグは，軽量であるうえ，内 部摩擦角が大きいため，裏込材として利用した場合に は土圧の軽減による経済的な断面を得ることが可能で ある、また，アルカリ刺激のもとで固結する性質があ るため，固結すれば液状化に対する抵抗性が高くなる 材料である。

(3)再生 PET 樹脂を用いた防砂シート

図-3に示す防砂シートは, 裏込内一の土砂の侵入を 防止するために用いられる. 再生 PET 樹脂を用いた防 砂シートは，通常用いられる合成樹脂系の防砂シート と同様な性質を有する。これは，ペットボトルの素材 はPET 単一の素材であり, ポリエステル繊維にリサイ クルしやすく, 再生した PET 樹脂はバージン PET 樹 脂と殁よ゙变わらない品質を有するためである.
(4)鉄鋼スラグ水和固化体

鉄鋼スラグ水和固化体を構成する材料である製鋼ス ラグは，臨海部に立地する製鉄所から毎年数 100 万卜 ン発生しており入手が容易であること，海藻などの生 物の育成に好適な元素を多く含むという性質を有する こと，鉄分を多く含み高比重で波浪安定性が良いとい う物理条件などから，異形ブロック，根固方塊などの 港湾土木材料に適している。

\section{(3) グリーン調達適用事例集}

平成 16 年 10 月から 17 年 8 月までに港湾・空港工事 に調達された表-1 に示す環境物品の適用事例を調査 し，事例集としてまとめ，調達担当者の支援ツールと して供することにした．各環境物品の適用件数を表-2 に示す。

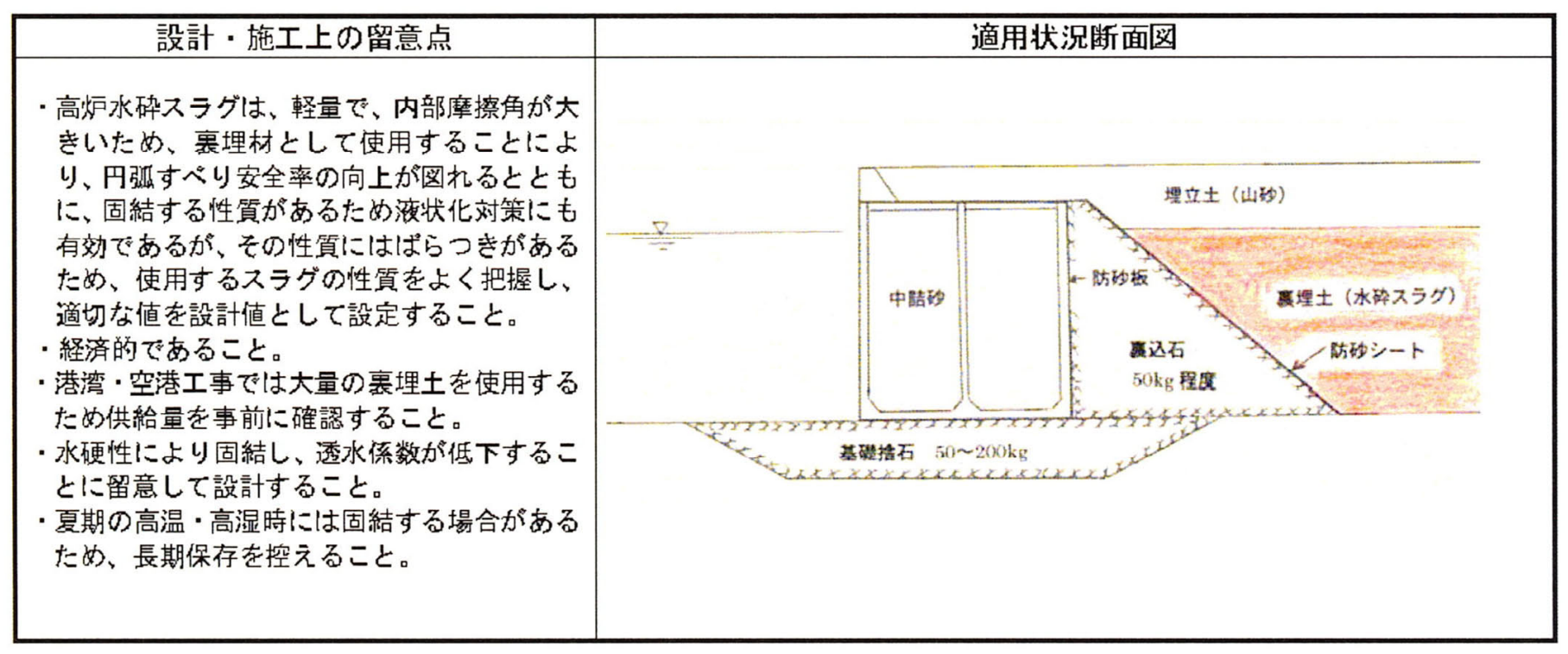

図-3 裏埋工への水砕スラグの適用例及び吸出防止工への再生 PET 樹脂を用いた防砂シートの適用例

表-2 港湾・空港工事における環境物品調達件数（平成 16 年 10 月〜平成 17 年 8 月)

\begin{tabular}{|c|c|c|c|}
\hline & 環境物品名称 & 指定の種類 & 港湾・空港工事での調達件数 \\
\hline \multirow[t]{2}{*}{ 建設副産物 } & 再生骨材等（コンクリート塊） & 特定調達品目 & 22 \\
\hline & 建設污泥から再生した処理土 & 特定調達品目 & 0 \\
\hline \multirow[t]{5}{*}{ 製鉄副産物 } & 高炉セメント & 特定調達品目 & 92 \\
\hline & 高炉スラグ骨材 & 特定調達品目 & 1 \\
\hline & 土工用水砕スラグ & 特定調達品目 & 3 \\
\hline & 地盤改良用製鋼スラグ & 特定調達品目 & 0 \\
\hline & 鉄鋼スラグ水和固化体 & ロングリスト品目 & 0 \\
\hline \multirow{2}{*}{$\begin{array}{l}\text { フェロニッケルス } \\
\text { ラグ製造副産物 }\end{array}$} & フェロニッケルスラグ骨材 & 特定調達品目 & 3 \\
\hline & フェロニッケルスラグを用いたケーソン中詰め材 & 特定調達品目 & 2 \\
\hline \multirow[t]{2}{*}{ 製銅副産物 } & 銅スラグ骨材 & 特定調達品目 & 5 \\
\hline & 銅スラグを用いたケーソン中詰め材 & 特定調達品目 & 8 \\
\hline 再生ブラスチック & 再生 PET 樹脂を用いた防砂シート (吸出し防止材) & 特定調達品目 & 7 \\
\hline 再生コンクリート & コンクリート殼を用いたコンクリート & ロングリスト品目 & 0 \\
\hline \multirow[t]{2}{*}{ その他 } & 天然䌍維を用いたドレーン材 & ロングリスト品目 & 0 \\
\hline & 生分解性プラスチックを用いたドレーン材 & ロングリスト品目 & 0 \\
\hline
\end{tabular}


(1)高炉セメント

表-2 より, 高炉セメントの適用件数が非常に多いこ とが分かる．高炉セメントは港湾構造物だけでなくセ メント系深層混合処理工法などの地盤改良の固化材と してもよく使用されている.

(2)再生骨材等

次に適用件数が多い再生骨材等（コンクリート塊）

は，ほとんど路盤材として砂利の代替として使用され ている，再生骨材等（コンクリート塊）は，環境的な 配慮による天然資源からの砕石生産の抑制や建設リサ イクル法 ${ }^{4)}$ による建設廃棄物の再資源化要請とあいま って適用事例が増加している. 港湾で発生するコンク リート塊の発生源であるコンクリート構造物は，建築 構造物に比べて構造がシンプルで鉄筋以外の混合物が 少ないという特徴を有している.このため, コンクリ 一トの破砕，再生利用が行いやすい特徴がある。その 一方で, コンクリートに大量の塩化物が含まれている というデメリットもある. 利用に当たっては，この点 について十分に検討する必要がある.

写真-1 に示す再生骨材等は岸壁腹付工の雑石の代 替として用いられたものである。

(3)コンクリート用スラグ骨材

コンクリート用スラグ骨材（高炉スラグ骨材，フェ ロニッケルスラグ骨材, 銅スラグ骨材) は, 3 種類合 わせて 9 件の適用がある. 用途は，根固ブロック，被 覆ブロック，消波ブロック，バラストコンクリート， 蓋コンクリート，上部工コンクリート等に使用されて いる. この内フェロニッケルスラグ骨材の比重は天然 細骨材と比べ 10〜25\%程度大きく, 銅スラグ骨材の比 重は天然細骨材と比べ30～50\%程度大きい.この特質 は，特に浮力の影響を考慮する必要がある消波ブロッ クなどの細骨材に用いることにより効果的に利用でき る.
(4)フェロニッケルスラグあるいは銅スラグ

フェロニッケルスラグあるいは銅スラグを用いたケ ーソン中詰材は, 合わせて 10 件適用されている.これ らの事例では，設計時からこれらの材料が砂より単位 体積重量が大きいことを利用してケーソンを設計して いる.

(5)再生 PET 樹脂を用いた防砂シート

再生PET樹脂を用いた防砂シートは7件の適用事例 がある. 再生 PET 樹脂を用いた防砂シートは容器包装 リサイクル法 ${ }^{5)}$ リよりペットボトルを防砂シートに再 製品化した材料で，ペットボトルを $100 \%$ 再生した製 品であるが，最近原料が不足気味であるため，調達に 当たっては通常品とのコストに隔たりがないか確認し ながら調達していくことが望ましい.

(6)土工用水砕スラグ

土工用水砕スラグは, 埋戻材として使用されている. 事例集には，上記環境物品を適用した各工事につい て, 施工場所, 適用施設, 適用部位, 施工数量, 施工上・ 調達上の問題点の有無, コスト等についてまとめている.

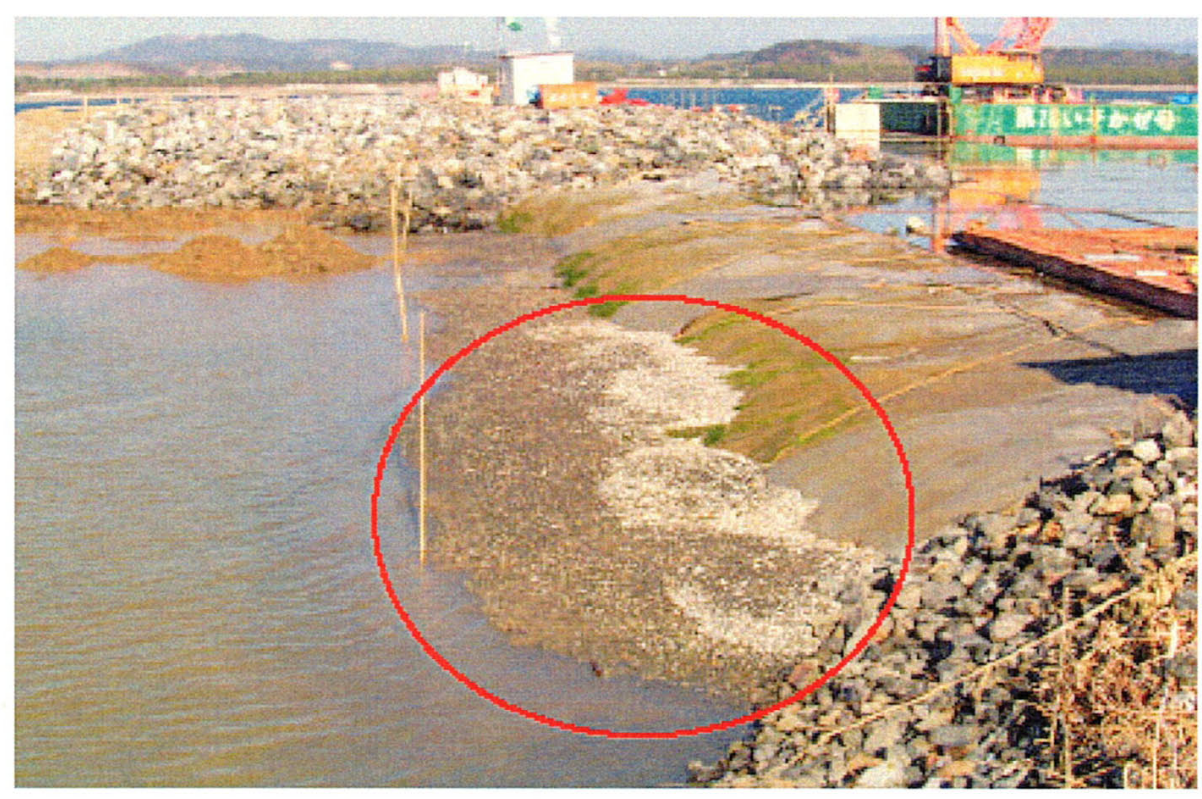

写真-1 腹付工（再生骨材等 $40 \mathrm{~mm}$ 以下）の適用事例（志布志港） 


\section{4. 結論}

わが国は循環型社会づくりを目指して廃棄物処理法, 容器包装リサイクル法, 家電リサイクル法, 建設リサイ クル法, 食品リサイクル法, 自動車リサイクル法, 資源 有効利用促進法およびグリーン購人法を制定し，廃棄物 の適正処理とリサイクルの推進を図っている.これらの 法令すべてが有効に機能することによって，環境負荷低 減を達成することが本来の目的である.

本研究はその一部の役割を担う公共工事におけるグリ ーン調達を推進するために，港湾・空港工事におけるグ リーン調達の現状を調査し，グリーン調達推進策を検討 した．そして，グリーン調達担当者の環境物品に対する 理解を高めるためのツールとして，グリーン調達品目の 解説資料とグリーン調達適用事例集を作成した.

今後の課題として, 設計・施工上の技術的な諸課題と 環境負荷低减効果を評価する仕組みに関する課題を以下 に詳述する.

(1)設計・施工上の技術的な諸課題

ロングリスト品目として継続検討されている環境物 品に関する技術的な課題としては, 主に施工実績が少 ないことにより, 使用する際の設計・施工方法の検証・ 評価が出来ないことがあげられる.

例えば生分解性プラスチックを用いたドレーン材に おいては，生分解速度のモニタリング年数の不足や海 上での施工実績がないことなどにより，実際と同等の 条件下での検証及び評価が十分出来ないことが課題と してあげられる。

(2)環境負荷低减効果を評価する仕組みに関する課題 今後の課題は, 環境物品之通常品のコストについて 客観的に評価できる手法の開発である.

例えば, 雨物品を購入価格だけで比較すると環境物 品のほうが高い場合もあるが, 環境負荷低減の部分を 貨幣換算し両方の合計でコストを比較できるような 手法の導入について研究が必要であると考えられる.

著者らは, 現在, ライフサイクルアセスメントの手 法を適用して, 港湾構造物の設計・施工・維持管理ま での一連の過程についての環境負荷低減効果を定量 的に試算できる手法について研究開発を進めていく 予定である.

\section{5. おわりに}

グリーン調達の推進のための支援ツールとして作成し た環境物品の解説資料およびグリーン調達適用事例集は, 現在調達担当者に配布して利便性をテストしているとこ ろである. 解説書は, 今後の技術開発の動向や新規に指 定された品目に対応するとともに，現場での調達にかか る諸課題を蓄積して解説書の技術的な内容を充実させて いく。また，ロングリスト品目を現場にて試行的に施工
したデータについても集積させて，これらの問題点を解 決するための技術開発を行っていく所存である.

謝辞：グリーン調達の実績及び適用事例のデータを提供 していただいた国土交通省港湾局建設課、各地方整備局 及び北海道開発局、沖縄総合事務局の関係諸氏には感謝 の意を表します。

\section{参考文献}

1) 三ツ木 浩剛 : 公共工事におけるグリーン購入法への取 り組み，建設マネジメント技術，PP18-19，2004

2) 内藤了二 : 港湾・空港等整備におけるリサイクルガイド ラインについて, 建設リサイクル Vol..17 秋号, PP18-21, 2001

3) 有田正史 : 砂の需給動向とその対応策 需要と供給を結 ぶ骨材供給ブロックの構築を, これからの細骨材, pp.19-25, セメント新聞社, 2004

4) 建設リサイクルハンドブック編纂研究会:建設リサイク ルハンドブック 2004, pp.24-39, 大成出版社, 2004

5) 石川禎昭編著 : 図解循環型社会づくりの関倸法令早わか り, pp.203-242, オーム社, 2002 